\title{
THE ORIGINS OF INEQUALITY, AND POLICIES TO CONTAIN IT
}

\author{
Joseph E. Stiglitz
}

This paper critiques the notion that unfettered inequality is an inevitable consequence of contemporary capitalism, and provides an alternative, new framework for analyzing changes in income and wealth distribution. By thinking of these distributions as the result of changing centrifugal and centripetal economic and political forces, we can identify changes in our economic and social structure that may have played a central role in the creation of today's high level of inequality, and we can analyze the potential impacts of alternative policies. Specifically, I suggest that much of the increase in inequality is associated with the growth in rents - including land and exploitation rents (e.g., arising from monopoly power and political influence).

Keywords: wealth inequality, taxation, scope of government

JEL Codes: E2, E6, H1, H2, H3

host of books in recent years have called attention to the country's - and the world's - increasing inequality, attempting to assess its dimensions, causes, consequences, and perhaps most importantly, what can be done about it. These include my own book, The Price of Inequality: How Today's Divided Society Endangers Our Future (Stiglitz, 2012) and, most recently, Thomas Piketty's tome, Capital in the Twenty-First Century (2014). ${ }^{1}$

Perhaps reflecting the influence of these books, inequality has risen to the top of the nation's agenda. In 2013, President Obama promised to make it the center of focus for the remaining three years of his term. (Obama described "a dangerous and growing inequality and lack of upward mobility” in a December 2013 speech, one of several

\footnotetext{
${ }^{1}$ Other books on the topic include Galbraith (2012), Milanovic (2010), Noah (2012), Wilkinson and Pickett (2010), and Bourguignon (2012).
} 
times he has highlighted the issue. "I believe this is the defining challenge of our time: Making sure our economy works for every working American." ${ }^{2}$ ) At Davos, business leaders have listed inequality as the world's most pressing problem. ${ }^{3}$

\section{AMERICA'S GROWING INEQUALITY}

All of this attention should not come as a surprise. America's inequality has grown enormously over the past 35 years, to the point where the upper 1 percent receives more than a fifth of all the nation's income. ${ }^{4}$ Wealth inequality is even greater: the top 1 percent own about 42 percent of the wealth, and the top 0.1 percent alone own 22 percent (Saez and Zucman, 2014). And while the share of income garnered by the top 1 percent has doubled in the last third of a century, the share going to the top 0.1 percent has increased even more, going up nearly threefold as of 2013 (Picketty and Saez, 2003, with tables updated to 2013).

The recession made all of this worse. Ordinary Americans were hurt badly by the loss of jobs and houses, and according to the Picketty and Saez data, the typical American didn't see any recovery even after the recession officially ended: 91 percent of all the increase in the first three years of the "recovery" went to the top 1 percent. An economy that is not creating benefits for most of its citizens is a failed economy. ${ }^{5}$ The impact of the recession on wealth inequality was even more devastating, with median wealth sinking back to levels from 25 years ago, 40 percent below pre-crisis levels (Boshara, Emmons, and Noeth, 2014; Bricker et al., 2014).

Most disturbing were two points that I emphasized in my book: America has the highest level of inequality of any of the advanced countries, and America has among the lowest levels of equality of opportunity (Stiglitz, 2012). ${ }^{6}$ As I put it, the American Dream is largely a myth. Of course, some very talented individuals do rise from the bottom to the top, and this fact is an enormous strength of the country. But the life chances of a young American are more dependent on the income and education of his or her parents than is the case in other advanced countries - even most of those in old Europe.

What has happened in America has reversed long-standing beliefs about both the nature of American society and the evolution of economies. We believed we had become

\footnotetext{
2 "Remarks by the President on Economic Mobility," December 4, 2013, Washington, DC, http://www. whitehouse.gov/the-press-office/2013/12/04/remarks-president-economic-mobility/. Obama has emphasized his concern about inequality on several other occasions, including in his January 28, 2014 State of the Union address, https://www.whitehouse.gov/the-press-office/2014/01/28/president-barack-obamasstate-union-address, and in a December 6, 2011 speech at a high school in Osawatomie, Kansas, https:// www.whitehouse.gov/the-press-office/2011/12/06/remarks-president-economy-osawatomie-kansas.

${ }^{3}$ The World Economic Forum's January 2015 discussion paper, "Benchmarking Inclusive Growth and Development," http://www3.weforum.org/docs/WEF_Inclusive_Growth_Development.pdf, set the tone for the meetings this year.

${ }^{4}$ Piketty and Saez (2003), with data updated through 2013.

${ }^{5}$ Stiglitz, Sen, and Fitoussi (2010) discuss the fact that GDP is not a good measure of economic performance.

${ }^{6}$ There is much additional literature on the subject, including Jäntti et al. (2006) and Corak (2013).
} 
a middle class society and the strength of the middle class was the strength of America. Not only is the middle class shrinking in size - with more people in poverty — but the incomes at the top have pulled away from those in the middle. While the average productivity of workers has doubled since 1970, wages for many workers have barely increased $^{7}$ and yet the incomes of the top 1 percent have soared, increasing by 170 percent, according to Piketty and Saez's data.

While most serious economists have always been skeptical of notions of trickle down economics - that if the top does well, so does the rest of society - what has happened in the last third of a century bears testimony to just how wrong that theory is: those in the middle have had stagnant incomes for a quarter of a century, and the wage of a full time male worker, adjusted for inflation, is lower than it was forty years ago. ${ }^{8}$

In the middle of the $20^{\text {th }}$ century, Nobel Prize-winning economist Simon Kuznets argued that while there is growing inequality in the initial stages of development, eventually, inequality is reduced. There is a plausible argument for this pattern: industrial wages exceed agricultural wages, so that with urbanization and industrialization, as more and more people go from low-income rural to more highly paid urban jobs, standard measures of inequality increase. Eventually, urbanization dominates. With so few in the rural sector, their relatively low incomes have little impact on inequality and, finally, incomes in the rural sector increase. America seemed to follow this pattern until around 1980. In the years after World War II, the agricultural sector shrank rapidly (dropping below 2 percent of employment by the $21^{\text {st }}$ century), ${ }^{9}$ and America became a middle class society. All parts of the society saw their incomes rise, but those at the bottom saw their incomes rise faster than those at the top.

Since 1980, Kuznets's vision has been destroyed. The growth of the economy as a whole was slower than in the decades after World War II, and it was not shared prosperity. This, in part, accounts for the new agenda being put forward by some: rather than relying on trickle down economics, this alternative vision says we can and should build the economy from the middle, as we did in the period following WWII.

While Piketty takes a much broader view - he is not interested in the separate variants of capitalism, such as American style capitalism, but in the underlying forces - much of what has happened in the United States has occurred elsewhere. The United States may have more inequality, but inequality has been rising in most (but not all) countries, especially in the advanced countries (Organisation for Economic Co-operation and Development, 2011). There is an important implication of this: Americans often have an American-centric view, trying to blame or credit one

\footnotetext{
${ }^{7}$ Shierholz and Mishel (2013) discuss how real U.S. wages have stagnated for decades. Adjusted for inflation, average hourly earnings of production and non-supervisory employees have decreased some 30 percent since 1990; see "Average Hourly Earnings of Production and Non-Supervisory Workers," Federal Reserve Bank of St. Louis, http://research.stlouisfed.org/fred2/series/AHETPI/.

8 "Historical Income Table P-36," U.S. Census Bureau, http://www.census.gov/hhes/www/income/data/ historical/people/.

9 "Percent of Employment in Agriculture in the United States," Federal Reserve Bank of St. Louis, http:// research.stlouisfed.org/fred2/series/USAPEMANA.
} 
party or another with the positive and negative changes in our economy. Piketty's book, in effect, warns us against this reasoning, as there appear to be global forces at work.

Piketty's insight is that the period after World War II - the period in which I grew up, and which I didn't realize at the time was the golden age of capitalism - was unusual. He seems to suggest that a high and even growing level of inequality is almost an inevitable consequence of capitalism. I say almost because he suggests that there are some policies - like a global capital tax — which might arrest it. But most discouraging is the fact that the policy on which he focuses the most seems totally out of reach.

Ever-rising inequality is depressing not only for what it would imply for our society and our democracy, but even for our economy. There has been a marked change in thinking about the consequences of inequality. It used to be thought that to do anything about inequality would require higher taxes that would weaken incentives and thereby weaken the economy. Arthur Okun, chairman of the Council of Economic Advisers under President Johnson, referred to this as "the big trade-off" (Okun, 1975). By contrast, the major thesis of my book is that we are paying a high price for inequality — at least at the extremes it has reached in the United States and in the way that it has been generated. We could have a stronger economy, higher growth, and less instability if only we did something about our outsized inequality. This view has now, in fact, become the mainstream view, with support from the IMF (Berg and Ostry, 2011) and others (e.g., Galbraith, 2012).

In this essay, I focus on two questions: What has given rise to this inequality? What can be done about it? In particular, is rising inequality largely the inevitable consequence of market forces (capitalism in the $21^{\text {st }}$ century), about which there is little we can do, at least little in the realm of practical politics?

The major thesis of this essay (and my book) is that our inequality is not, for the most part, the result of economic forces. It is not, in this sense, the result of inexorable economic laws. Rather, it is the consequence of our policies, and in turn, a reflection of our politics. Yes, there are economic forces at play that are dividing the country, but even these forces are shaped by — and sometimes driven by — our policies. The strongest evidence in support of this perspective is that inequality is so different in countries with similar economic structures. The laws of economics operate similarly on both sides of the Atlantic. Yet America's inequality is greater than elsewhere, and those countries that have followed America's economic model have seen a similar (but not quite as great) increase in their inequality. Of course, what happens here has effects elsewhere; our policies are contributing not only to inequality here, but also to inequalities abroad. Thus, I would argue that the real issue is not capitalism in the $21^{\text {th }}$ century, but politics in the $21^{\text {th }}$ century.

There is a vicious circle in our democracies. Wealth and income inequality translate into political inequalities, especially in the United States, where our legal framework provides great scope for the influence of money. But then these political inequalities translate back into more economic inequalities. 


\section{THE CAUSES OF THE INCREASE IN THE WEALTH-INCOME RATIO}

\section{A. Piketty's Narrative}

Piketty presents a simple story of growing inequality. If those at the top save all of their income, their wealth grows at the rate of return on capital $(r)$, and if $r$ is greater than the rate of growth of the economy, wealth grows faster than income as a whole, and so too for their income (so long as the rate of return on capital does not diminish - which he suggests has not happened and is not likely to happen). He interprets the increase in the wealth-income ratio observed in many advanced countries as providing support for this hypothesis. He also sees the increase in the wealth-income ratio as essentially an increase in the capital-income ratio, and thus what economists would call capital deepening.

\section{B. Skepticism About This Narrative}

Many economists have been skeptical of this story on several grounds. Piketty's theory focuses on inherited wealth, and yet some (perhaps many) of those at the top of the income distribution did not inherit their wealth. The savings rate, $s$, even at the top, is far from 1: best estimates put the number around 0.35 (Carroll, 1998; Dynan, Skinner, and Zeldes, 2004; Piketty and Zucman, 2014). If that is the case, then $r$ can be considerably greater than $g$, and yet $s r$ - which would determine the pace at which the wealth of the capitalists would accumulate — will be less than $g$. Many at the top seem not to invest their money well, with investment and consumption often becoming blurred as their wealth is put into extravagant houses, horses, wineries, and art. The upshot is that wealth is often not perpetuated. As I observed in a recent paper presented at the $17^{\text {th }}$ World Congress of the International Economic Association (Stiglitz, forthcoming),

John D. Rockefeller was America's first billionaire. At death, in 1937, his assets amounted to 1.5 percent of GDP. Had his assets grown at the rate $g$ (the rate of growth of the economy) they would be worth today some $\$ 340$ billion. If $r$ (the relevant rate of return) were just 1 percent more than $g$, their family wealth should have grown to $\$ 680$ billion. If, using numbers that Piketty might say are still conservative, but more realistic, the disparity between $g$ and $r$ is 2 percent, their wealth would have been $\$ 1.3$ trillion. Instead, the total value of the family assets is estimated to be $\$ 10$ billion - less than 1 percent of the predicted amount — divided among almost 300 members (Roberts, 2014). ${ }^{10}$

\footnotetext{
${ }^{10}$ It appears from this story that Piketty's analysis seems to have overestimated " $r$," overestimated the extent to which returns were reinvested, and underestimated the importance of the division of wealth among one's heirs.
} 


\section{The Rate of Interest is an Endogenous Variable}

Most importantly, the rate of interest is an endogenous variable. One of the most deep-seated beliefs among economists is the law of diminishing returns. Surely, with all of this capital deepening that Piketty suggests has been happening, the rate of return on capital should fall. If it doesn't, we have to rethink our basic models, and in ways far more profoundly than those offered by Piketty.

\section{The Puzzle of Movements in Factor Returns}

There are other disquieting aspects of growing inequality, especially in America, but also elsewhere, that are hard to reconcile with standard economic theories. Normally, capital deepening would be expected to raise labor productivity, and thereby wages. But wages have stagnated. (The numbers are even worse if the wages of the top 1 percent are excluded - the pay of bankers, CEOs, etc. - in which case there has been a dramatic decline in the income share of wages (Giovannoni, 2014, 2015).) While some have talked a lot about skill-biased technological change (which would increase the productivity of some workers at the expense of others), one can show in the standard model that average and marginal productivity — and in competitive markets, therefore the average wage - should have still increased.

\section{The Puzzle of the Pace of Increase in the Value of Wealth}

One thinks of wealth accumulation as a steady process, of setting aside some of one's income every year, not consuming it, but rather investing it. But with America's low savings rate (the average net national savings rate of the United States over the period 1970-2010 was 5.2 percent), ${ }^{11}$ one can account for only about half of the increase in the value of wealth.

\section{Long-Run Determinants of the Wealth-Income Ratio}

Finally, Piketty takes a long-term perspective, and it is therefore natural to ask: what determines the wealth-income ratio in the long run? Is it conceivable that the parameters describing the economy have changed, say, over the past 40 years, in ways that would lead to an increase in the wealth-income ratio, especially of the magnitude observed in some countries? Economists have formulated a large number of growth models (all within the neoclassical tradition, where output is a function of capital and labor, but differing in the determinants of savings). In each model, the equilibrium capital-output ratio increases with the savings rate and decreases with the long-run growth rate. ${ }^{12}$ In

\footnotetext{
${ }^{11}$ Part, but only part, of the "wealth residual" (the unexplained portion of wealth accumulation) can be explained by net capital inflows.

${ }^{12}$ The long-run growth rate in turn is the sum of the long-run rate of increase of the work force plus the rate of labor augmenting technological progress.
} 
the United States and many other countries, the savings rate has decreased, while the growth rate has fluctuated, increasing in the years after World War II, and again in the Clinton years, but diminishing more recently. But the movements in the wealth-output ratio do not seem to reflect these changes well, either qualitatively or quantitatively.

\section{Capital Is Not to Be Confused with Wealth}

There is a simple resolution to these conundrums. Much of the increase in wealth has little to do with savings in the usual sense. Rather it is the result of capital gains - especially the increased value of land - and an increase in the capitalized value of other rents. It is a mistake to confuse capital with wealth. Capital is, of course, an aggregation, somehow, of different capital goods. For purposes of assessing control over resources, a natural way to aggregate is to use market values. But market prices may or may not be a good way of aggregating these factors of production for purposes of assessing whether "inputs" into the production process have increased, and quantifying whether they have increased more than the supply of labor (i.e., whether there has been capital deepening). ${ }^{13}$ The value of houses soared in the years before the crisis; this is part of our "capital stock." But no one would say that the capital input into the production process increased commensurately. Quite the contrary, the relevant measures of plant and equipment may have increased relatively little compared to GDP. In some countries, they may even have declined.

\section{The Significance of Land}

The distinction between wealth and capital is especially evident once land is taken into account. The value of land on the seashore may be going up, but that doesn't mean, in a real sense, the country is "wealthier" (though obviously, the owners of that land have more paper wealth). Since land is not increasing, if land is a factor of production (which it is, at least when it comes to the production of housing services, which constitute a quarter of GDP), then if we are to talk about an aggregate input, we have to weigh together the fixed land supply with increasing capital. When we do this using the best national income accounting ("aggregation") techniques, it turns out that the aggregate input ("land plus capital") is actually diminishing relative to GDP, at least for some advanced countries.

Similar to the increase in real estate values is the increase in the value of depletable natural resources, like oil, gas, iron, and copper. Economic theory (Hotelling, 1931) predicts that the price of these natural resources should increase over time; such increases are essential to efficient allocation of these resources over time, and would occur even in the absence of their increasing scarcity relative to labor, capital, and other inputs. Globally, much of the inequality at the top is related to ownership and

\footnotetext{
${ }^{13}$ Domestic capital deepening could also occur because of inflows of foreign capital, but such inflows do not change the basic picture described here.
} 
control of such resources, including oil-rich sheikhs in the Middle East and the Russian oligarchs. (And, of course, this oil and mineral wealth gets translated in part into real estate wealth, as they demand residences in London and New York and homes in the Riviera and Southampton.)

The fact that capital in any productive sense is not increasing as fast as wealth helps explain part of the anomalies; it could help explain the failure of the return to capital to fall, or even the failure of wages to rise as much as one would have expected.

\section{E. Exploitation Rents}

But there is, I believe, something else going on: an increase of what might broadly be called exploitation rents. With the large inequalities that marked early capitalism in the $18^{\text {th }}$ and $19^{\text {th }}$ centuries, two broad strands of thought emerged: one seeking to understand the evolving distribution in terms of exploitation and market power, the other in terms of social contribution (the marginal productivity theory, what I will refer to below as the "neoclassical model," which is the standard one taught in conventional economics courses). There is some truth in both views. In some parts of the economy, there is strong competition, with factor prices reflecting productivities, but in others, competition is more limited. The incomes of owners in the United States and elsewhere was a result of oppression and exploitation, but the exploitation continued long after, with discrimination still a part of the American economy.

In the late $19^{\text {th }}$ and early $20^{\text {th }}$ centuries, there was much concern about "monopoly capitalism." Rockefeller and Carnegie made their fortunes through monopolies. Today's capitalism is different, and perhaps in some areas even more immune to anti-trust laws. Network externalities have given real market power to a few firms and the move to a service sector economy may have resulted in greater scope for more local market power.

Much of the rents are derived by the use of political influence. The railroad barons of the Gilded Age made their fortunes in part through land grants from the U.S. government. Some of the top fortunes today can be traced either to the exploitation of market power or to grants of rents from the government. In many cases, the different forms of rents interact. Grants of zoning variances create wealth for real estate moguls; the provision of the 2003 law providing coverage for drugs for Medicare recipients that said that the U.S. government, the largest purchaser of drugs in the world; could not bargain over prices provided an estimated trillion dollars to the drug companies, preferential provisions of the tax laws provide trillions more to other special interests, and the giving away of the country's natural resources (or sales at below competitive prices) provide trillions more. The financial sector combines a variety of forms of exploitation rents, which have contributed to both the inequalities at the top and the bottom: predatory lending and abusive credit card practices provide rents derived from exploiting the poor based on imperfect information and knowledge; market manipulation, evidenced in the LIBOR and FOREX scandals, also generates rents based on imperfect and asymmetric information, but this time, mainly exploiting others who are better off; the huge interchange fees associated with credit and debit cards provide rents based on market power 
related to the control of the payments mechanism. Insider trade and the sophisticated front running associated with high frequency trading (Lewis, 2014; Stiglitz, 2014a) generate other forms of rent, as does the trading in credit default swaps and derivatives, based on non-transparent over the counter trading. As the financial sector has grown to account for 8 percent of GDP, garnering for itself 40 percent of all corporate profits in the years before the crisis ${ }^{14}$ - with little to show for its activities in terms of economic performance, either in growth or stability - it has become increasingly hard to reconcile its returns with the neoclassical model.

\section{F. Evidence in Support of the Exploitation Model}

Though there is no way to "prove" which model — the exploitation model or the neoclassical model - provides more insights into the origins of our increasing inequality, a number of pieces of "evidence" are suggestive. If we look at the Forbes 100 list of the wealthiest people, it is striking that it does not include those who have made the most important contributions to the advances in our standards of living - the discoverers of the transistor or the laser, those whose insights led to the invention of the computer, the Internet, or advances in modern medicine, or the discoverers of DNA. They do include those who have made important contributions to commerce, but their wealth is often the result of amplifying these contributions through the exertion of market power - as in the case of Bill Gates. The basic laws of competition limit the wealth that any individual can, in a short period of time, accumulate without the exercise of some monopoly power. Similarly, if we look across sectors of the economy, it is remarkable in how many rent seeking (either based on the exertion of private market power or extraction of rents from the public sector through the exercise of public influence) is so evident: agricultural, health, natural resources, telecommunications, and high-technology.

The recession provided more evidence. Bank officials, whose contributions to society, and even to their firms, were clearly negative, nevertheless received huge bonuses - a disconnect between compensation and contributions. But for those who had studied executive compensation, this had long been evident. There was no increase in productivity of managers that could justify the huge increases in their compensation over the past 35 years. Moreover, the form of compensation - linked to stock market prices, as much determined by changes in interest rates and other factors well beyond the control of the executives as by performance - showed that there was not even an attempt to closely link contribution and pay.

Piketty, with his co-authors, provided further evidence. Looking across countries, they observed that increasing taxes at the top did not lead to slower growth (Piketty, Saez, and Stantcheva, 2014). Under the neoclassical model, one would have expected the higher taxes to discourage effort and thus lower growth; under the exploitation model, higher taxes might discourage rent seeking, but this could even be good for the economy.

\footnotetext{
14 “Table 6.16D. Corporate Profits by Industry," National Income and Product Accounts, Bureau of Economic
} Analysis, http://www.bea.gov/National/nipaweb/SelectTable.asp. 
Most importantly, though, the exploitation model provides a ready interpretation of the seeming anomalies uncovered earlier. When the rights to rents can be bought and sold, they get capitalized. Increases in monopoly power show up simultaneously in higher profits, lower wages, and a higher value of "capital." If mining companies get more access to valuable natural resources on government-owned land at below-market prices - or the gap between what they have to pay and the fair market value increases - then the value of these mining companies increases. Changes in bank regulations, which allow them to undertake more risk, increase the chances of a bailout and thus the expected value of transfers from the government. The value of these transfers will be capitalized in the value of the banks, and thus the change in regulations will be reflected in an increase in the value of these institutions. One should not misread this as an increase in the wealth of the country. In each of these instances, the true wealth of the economy is unchanged or diminished. An increase in monopoly power shifts wealth from workers to the owners of the firms with market power, but the decrease in the wealth of workers is not recorded, while the increase of the value of firms is. Because of the market distortion associated with the exercise of market power, societal welfare is actually lowered. Increased transfers of money from the public to the private sector similarly increase the wealth of the banks, but decrease the wealth of taxpayers. The former is recorded, the latter is not, and because of the distortion, overall wealth is lowered.

The exploitation theory can thus simultaneously explain the increase in the wealthincome ratio, the stagnation of wages, and the failure of the return to capital to fall. Much of the story of the increase in inequality in the United States is the increase in the wealth-income ratio, without a decrease in its return. Simple arithmetic means that if that happens, the share of capital in national income increases; since capital is more unequally distributed than labor, it follows that such a change would result in an increase in the measured inequality of income. These factors explain what might account for the increase in the wealth-income ratio and what might simultaneously account for the seemingly paradoxical failure of the return to capital to fall. But what gives rise to the increase in both land and exploitation rents? I will have a few words to say about this later in this essay.

But this is not the full story, for as noted earlier, there has been an increase in concentration of wealth among capitalists. We also need to better understand the determinants of the rate of interest to see why it might not have fallen in the way expected, and why, since the middle of the $20^{\text {th }}$ century, there has been an enormous increase in life-cycle savings. We need to understand better the relationship between life cycle and inherited wealth. It turns out that these three issues are closely related.

\section{THE DETERMINATION OF THE RETURN TO CAPITAL}

\section{A. The Importance of the Savings Rate of Capitalists}

Central in Piketty's explanation of the growth of the capital- (wealth-) output ratio is the observation that the return to capital exceeds the rate of growth. Earlier, I suggested that so long as the savings rate of capitalists is less than unity, what matters is 
the relationship of $s r$ to $g$, where $s$ is the fraction of their income that they save. The wealth of capitalists increases at the rate of $s r$, so only if $s r$ is greater than $g$ will inherited wealth increase faster than national income. But $s r$ could plausibly be less than $g$ even if $r$ is greater than $g$. Indeed, that is the case for the numbers provided by Piketty and Zucman cited earlier for the United States..$^{15}$ Moreover, as capital accumulates, one would expect $r$ to decline. Economic theory ought to explain whether, in the long run, $s r$ could plausibly remain above $g$.

In fact, standard growth theory provided an answer to these questions a half century ago. I used such theories to develop a theory of the distribution of income and wealth among individuals in my Ph.D. thesis. ${ }^{16}$ In the long run, if all individuals save the same fraction of their income (as in the classic Solow (1956) model that defined neoclassical growth theory), then in the long run, $s r<g .{ }^{17}$ With $s$ being around a third, all that is required is that the rate of return to capital be less than three times the rate of growth; most studies suggest that this is the case now and the general theory argues that this will be true over the long run.

I showed that under this condition, if all families had the same wage, divided their income equally among their children, and had the same number of children, then wealth would eventually be fully equalized, regardless of the initial distribution of income. I had shown that what mattered was not the relationship between $r$ and $g$, but between $s r$ and $g$, and in the long run, inequalities would not persist because $s r$ would be less than $g$ (even though $r$ would be greater than $g$ ) in these simple models. There are, however, other forces giving rise to inequalities, which I discuss in the next section.

\section{B. The Implications of Differences in Savings between Capitalists and Workers}

First, I note that there are other frameworks generating somewhat different results. In the battles in the middle of the $20^{\text {th }}$ century over different views of growth, the Cambridge School (United Kingdom) argued that a better model than the Solow neoclassical model hypothesized that capitalists save a far larger fraction of their income than workers. In the long-run equilibrium, $s_{c} r=g$, where $s_{c}$ is the savings rate of capitalists. The rate of interest in long-run equilibrium was greater than the rate of growth, by just enough to offset the fact that capitalists save less than all of their income. In the long run, contrary to Piketty, the wealth of capitalists grows at exactly the same rate as the economy.

As I showed in Stiglitz (1969b), this has, however, a disturbing implication: any initial inequalities in wealth ownership (among the capitalists) are preserved. There is neither a tendency for wealth inequalities to increase or decrease. But if there is variability in the returns to capital, then inequalities in wealth grow increasingly large

\footnotetext{
${ }^{15}$ With the savings rate at the top of the income distibution around $1 / 3$, and $g$ around 2.8 percent, $s r<g$ so long as $r<8.4$ percent, which it clearly is on average.

${ }^{16}$ This work was presented in 1966 to the meetings of the Econometric Society in San Francisco, and subsequently published (in abbreviated form) as Stiglitz (1969b).

${ }^{17}$ Solow showed that $s Y / K=g$, where $Y / K$ is the output capital ratio. But $Y=w L+r K$, where $w$ is the wage rate, so it is immediate that $g=s r+(s w L / K)>s r$.
} 
over time. The fact, however, that those at the very top of the wealth distribution in the United States are not those who have had wealth accumulate over multiple generations suggests that this is not a good model for understanding the distribution of wealth, at least in the United States.

\section{Life-Cycle Savings and Taxes}

Late $20^{\text {th }}$ century capitalism in the United States and many other advanced countries was accompanied by an enormous increase in life cycle savings, as life expectancies grew far faster than retirement ages. The increase in (private) retirement savings was somewhat dampened by the growth of public retirement programs, but increased with the shift from defined benefit programs to defined contribution systems. ${ }^{18}$ One might have thought that these large amounts of retirement savings would have driven down the return to capital - perhaps even making $s_{c} r<g$, just as in the neoclassical model - leading towards the equalization of wealth. And that may have happened in the middle of the $20^{\text {th }}$ century.

But two forces worked in the other direction. First, and perhaps most importantly, changes in tax laws meant that the very rich actually faced lower tax rates than the not-so-rich, so that for them, $s$ times their after-tax returns was greater than the rate of growth. (We will return later to a more extensive discussion of taxation.)

Secondly, in the long run, there is a balance between dissaving of the retired and the saving of the young. In the long-run equilibrium, it turns out that even with life cycle savings, $s_{c} r=g$. The capital stock, rates of return to capital, and wage rates are all determined by the savings behavior of capitalists. Life cycle savings "crowds" out capitalists savings. The greater the life cycle savings, obviously the smaller the share of the country's wealth that is owned by the plutocrats — but that is the only effect. ${ }^{19}$

\section{CENTRIFUGAL AND CENTRIPETAL FORCES}

The best way of thinking about the changing distribution of income and wealth is to think of the economy being pulled apart by centrifugal forces - creating more inequality — at the same time that there are underlying centripetal economic forces dampening inequality. The equilibrium distribution of income and wealth reflects a balancing of these centrifugal and centripetal forces. Over time, the strength of, say, the centrifugal forces may increase, and this will lead to an increase in inequality. Such an "equilibrium" theory provides a better approach to thinking about what has been going on in recent decades than the notion that there are certain inexorable forces in capitalism leading to

\footnotetext{
${ }^{18}$ The shift from defined benefit to defined contribution systems would not have resulted in a change in wealth but a change in who controlled it, if the former had been fully funded. In defined benefit programs, the wealth would have resided within corporations. It would be a difficult task to attribute this wealth to the eventual recipients.

19 This result is developed in Stiglitz (forthcoming) but was anticipated in Pasinetti (1962).
} 
ever-increasing inequality. Rather, changes in economics and in policies have changed the balance between the two sets of forces. By identifying what these forces are, one is in a better position to "rebalance" the economy.

The fact that wealth compounds at the rate of interest obviously is an important centrifugal force, but the fact that only a fraction of wealth is reinvested and that $s r<$ $g$ in the basic neoclassical model means that wealth compounds at a rate slower than the growth of the economy; limitations on savings thus act as a centripetal force. The variability of returns to capital also leads to wealth and income inequality. Those who are lucky will give more wealth to their children, and if their children are also "lucky" they will be able to bequeath more to their children. In 1953, a brilliant colleague at Cambridge (United Kingdom), David Champernowne, formulated a simple stochastic model generating income and wealth distributions with fat-tails (more wealth in the extremes of the distribution than one would have expected with, say, a lognormal distribution) (Champernowne, 1953). In Stiglitz (1969b), ${ }^{20}$ I then showed that a stochastic variant of my neoclassical model satisfied the Champernowne conditions. Subsequently, in Bevan and Stiglitz (1979) (see also Bevan, 1979), I used more advanced techniques (employing diffusion models) to demonstrate that the level of inequality decreased with the size of $g-s r$ and increased with the variability of returns. But, as I noted earlier, $r$ itself is an endogenous variable, affected, for instance, by the savings rate itself. More recently, in Stiglitz (forthcoming), I show that the level of wealth inequality increases with the share of capital. The observed increase in the share of capital would thus be expected to lead to more inequality among wealth-holders; if the elasticity of substitution is less than one,${ }^{21}$ an increase in the capital-labor ratio (e.g., as a result of an increase in the savings rate or a reduction in the population growth rate) will lead to a decreased share of capital and less inequality. Of course, just the opposite happens if, in spite of the increase in the wealth-income ratio, the capital-effective-labor ratio declines. Either way, it reinforces my earlier conclusion: one cannot understand what is happening to inequality of wealth without taking into account the growth of rents.

Wage dispersions - especially in the extremes - give rise to wealth inequality. Those at the bottom accumulate no wealth, while those at the very top save enough not only for their retirement, but to pass on wealth to their heirs. If the wages of children were the same as those of the parents, wealth inequality would simply reflect these underlying wage disparities (compounded by the good and bad luck of the random returns on capital). But there is a process of regression towards the mean, and a faster pace of regression will result in less wage and wealth inequality. The aphorism "rags to riches and back to rags in three generations" reflects this perspective.

${ }^{20}$ This is the unpublished version of Stiglitz (1969b), which I presented at the December 1966 meetings of the Econometric Society in San Francisco.

${ }^{21}$ The elasticity of substitution describes how easy it is to substitute capital for labor. When the elasticity is low, an increase in capital (relative to labor) so diminishes the return to capital that the overall share of capital diminishes. 
The fact that the rich save so much more than the poor is a centrifugal force, as those who get large incomes (as a result of high wages or a high return on investments) will save more to pass on their wealth to their children. If the savings function (giving savings as a function of income or wealth) is S-shaped, then it is possible that the two-class model described earlier (a capitalist class whose income is largely based on wealth that saves at a high rate, and a working class with more limited savings, mostly for retirement) provides a good description of the economy. The inequality of wealth is not caused by the differences in savings functions - all individuals could have the same savings function - but the differences in savings rate simply reflect the endogenous distribution of income and wealth.

Dispersions in family size and in inheritance customs and law can also affect inheritances and wealth inequality. Primogeniture gives rise to high levels of inequality. If there is a high variability in family size, then, even with equal division, there will be a large dispersion in inheritances.

This framework allows us to think about how changes in the economy, society, and policies may have affected the centripetal and centrifugal forces. With the very rich paying a smaller tax rate on capital than the less wealthy, the centrifugal force of wealth-compounding has increased. In the standard neoclassical model, capital taxation reduces the variability of returns and hence tail-inequality. Thus a reduction in the average taxation of capital (even without the regressivity currently observed) leads to more inequality (unless offset by a corresponding fall in the before-tax return - see below).

There are many ways in which rich parents can transmit advantages to their children, including by providing them with a better education. Public education can thus be an important equalizing force. But if there is economic segregation (and there is evidence of an increase in such segregation), if schools are locally funded, and if schools in rich communities provide a better education than those in poor communities, then there will be more intergenerational transmission of advantages. The equalizing force of "regression towards the mean" will be dampened, as it will if there is more assortive mating, as a result of the rich and talented being more segregated into schools that are different from those attended by others.

The fact that advantages are transmitted across generations implies, of course, that societies, such as the United States, with high levels of economic inequality are likely to be marked by low levels of economic opportunity, a relationship that Krueger (2012) has labeled the Great Gatsby curve, ${ }^{22}$ which has also been shown to hold within the United States (Chetty et al., forthcoming). This is especially the case in the absence of government actions to "level the playing field," by providing all children, regardless of the income of their parents, access to good education and health care. Programs like Head Start are designed to partially undo some of the disadvantages facing the poor, and there is some evidence that such programs work (Heckman, 2011; Heckman, Pinto, and Savelyev, 2013). By the same token, the increase in inequality in the United

${ }^{22}$ Krueger's remarks were based on the work of Corak (2013). 
States in recent years suggests that going forward there will be still greater inequalities of opportunity, which will then translate into still greater inequalities in income and wealth.

\section{EXPLAINING THE INCREASE IN THE PRICE OF LAND}

Earlier, I argued that the basic neoclassical model could only explain part of the increase in income and wealth inequality. Much of the growth in inequality and the increase in the wealth-income ratio are related to an increase in rents and land values. In the middle of the last century, land was essentially dropped out of the models used by economists. After all, agriculture, the source of the major demand for land, had shrunk to a very small fraction of GDP. But as I noted earlier, housing services is an important component of GDP, and land values, especially in our urban areas, are an important part of housing services. Indeed, with urbanization, one would expect an increase in land values.

But there is more going on: land is a store of value. The value of land today is largely dependent on its expected value tomorrow, ad infinitum. This means that land prices are largely untethered. Rising expectations can, at least for a while, be self-fulfilling. Land bubbles have marked capitalism from its early days, and we have been going through just the latest instance. ${ }^{23}$ But even when there is a "correction," there is no assurance that the economy is not off on another bubble-path.

One of the main drivers of land prices (or the value of other non-produced assets) is credit availability. As quantitative easing made so abundantly clear, a flood of liquidity can drive up asset prices. This is especially easy because, as I noted, land prices are largely untethered. If credit is made available to those with collateral and provided at interest rates below the expected rate of return, there will be a heavy demand for those assets (like land) that can easily be used as collateral. Thus, changes in monetary and regulatory policies that lead to an expansion of credit will contribute to an increase in the value of land — to an increase in "wealth" — but not necessarily to an increase in the country's real capital stock.

Such monetary policies can contribute at the same time to growth in income and wealth inequality, and the mechanism by which this occurs represents a fundamental change in our understanding of the structure of the economy. In the $19^{\text {th }}$ century, analyses of monetary policy focused on impacts on creditors and debtors. The election of 1896 was fought on this issue: moving to the bimetallic standard would lead to higher prices, reducing the value of the debts owed by farmers to the banks. Thus, loose monetary policy was seen as pro-equality.

\footnotetext{
${ }^{23}$ Technically, they could be prevented if there were markets for land going out infinitely far into the future. The equilibrium conditions requiring the returns to land (rents plus capital gains) to equal the returns to capital goods imply that if the price is not "right," bubble prices can't be sustained, as demonstrated in the last episode. Formal models showing this have been developed by Stiglitz (forthcoming), Hahn (1966), and Shell and Stiglitz (1967).
} 
Similarly, in the post World War II era, looser monetary policies were associated with faster economic growth and higher employment, driving up wages. The excessive focus on inflation contributed to a ratcheting down of wages; when a recession occurred, wages stagnated, and workers did poorly. But as soon as the economy started to recover and unemployment fell, central banks, focusing on inflation, would raise interest rates, preventing workers from recovering in the upswing what they had lost in the recession.

Keeping interest rates close to zero seems to have contributed to wealth inequality, too. While this policy didn't stimulate the economy much (as predicted - though it may have prevented the economy from falling into an even deeper downturn), it hurt owners of short-term government bonds - older, risk-averse people who had acted conservatively — but helped the owners of equity, disproportionately the very rich. Earlier, I talked about two types of wealth holdings: life cycle and inherited. While the proportion of wealth in life cycle savings may be far higher than seventy-five years ago, there are important compositional differences in the two kinds of wealth holding. The very rich are able to bear more risk, and disproportionately own equities, so the low interest policy of the Federal Reserve, which advantaged equities, improved the fortunes of those at the top.

\section{EXPLAINING THE INCREASE IN EXPLOITATION RENTS}

There are several reasons for the increase in exploitation rents, some of which were noted earlier in this essay, including that changes in technology gave more scope for network externalities, and thus for market power. But there are other institutional and societal forces at play. Changes in mores led corporate executives to exploit weaknesses in corporate governance laws, and the weakening of unions meant that they were less able to check these abuses. An unintended consequence of the 1993 tax change - effectively imposing taxes on high executive pay unless it was performance related - was to encourage seemingly performance-related executive pay. Executives discovered new non-transparent ways of increasing their incomes, including by diluting shareholder holdings. Accounting rules gave them ample scope for doing so. Globalization - in the asymmetric way that it was done, without appropriate safeguards - and declining unionization weakened the bargaining power of workers. Deregulation of financial institutions allowed them to engage in more exploitive activities.

There were some opposing changes, but these proved less powerful than had been expected. Laws against discrimination and affirmative action programs did allow a larger number of minorities and women to be more successful; yet the average black-white gap in incomes remains unchanged, that in wealth has increased, especially after the recession, and the gender gap remains large.

Finally, there is little doubt that there has been an increase in the influence of money in politics. And because the size of government itself has increased, there are more opportunities and incentives for the wealthy and corporate interests to engage in rent seeking in the public sphere. The deregulation movement itself, especially in the financial 
sector, can be viewed as part of this rent-seeking agenda. President Eisenhower, in his farewell address, effectively warned against such rent seeking on the part of the militaryindustrial complex. But the list of successful rent seekers today is much larger, including the drug companies as well as those in oil, gas, and mining, and the financial sector.

Public policy has affected inequality in other ways. In some periods, there has been lax enforcement of antitrust laws, and even the limited rules governing, say, the financial sector. Lowering taxes on the wealthy may have actually encouraged rent seeking. It takes effort (and in some cases, rather unpleasant effort) to engage in rent seeking. Since so much of the return to rent seeking goes to those at the very top of the income distribution, when their tax rates are lowered, the benefits of rent seeking, relative to the costs (especially the personal costs) may be lowered.

\section{TAXATION AND OTHER PUBLIC POLICIES}

The previous section outlined some of the ways that public policy in recent years has contributed to the increase in inequality. In fact, every law and regulation and every policy potentially has an impact on inequality. Markets don't exist in a vacuum, and our laws and regulations determine how they operate. A bankruptcy law, such as ours, that gives owners of derivatives first claim helps derivatives; a bankruptcy law, such as ours, that makes student loans almost undischargeable even in bankruptcy, discourages borrowing for education and thus impairs upward mobility on the part of those who need loans to obtain a good college education.

So too for every expenditure program. Australia provides income contingent loans to every university student. Other countries provide large subsidies that lead to lower tuition. With a university education increasingly necessary for economic success, a tuition-financed system such as ours makes a university education less accessible in the United States than in other countries, reduces upward mobility, and thereby contributes to inequality.

Taxes in particular can have a large effect on inequality, as I noted earlier, but as always, one has to pay particular attention to tax-shifting. Consider, for instance, Piketty's central model in which capital accumulation is the result of capitalists saving a fraction (all) of their wealth. If in this world a tax is imposed on capital, the amount of savings/investment will be reduced, and the return to capital will increase. In the short run, Piketty is right that there will be a reduction in the capital-output ratio and a reduction in the extent of inequality among capitalists. But the lower level of investment will lead to a higher return to capital, and in the long run, the after-tax return will be exactly the same as before. There is no change in income and wealth inequality among capitalists. Moreover, because the capital stock is lower, wages will be lower. It can be shown (Stiglitz, forthcoming) that even if all the tax proceeds are redistributed to workers, they can be worse off. Quite different results are obtained if the tax is imposed on inheritances (and even better, if one taxes the returns to capital that are not part of life cycle savings), or if the government invests the tax proceeds, in which case, it may even be possible that there will not be a decline in wages. 
But full shifting only occurs in this special model, and only if the government does not invest some of the proceeds. If it does so, particularly in investments that increase workers' productivity (either investments in human capital or in technology or infrastructure that are complementary with labor), then wages can rise and the standard of living of workers can improve.

My analysis has shown that tax structures that tax inheritances and exempt life cycle savings from interest income taxes can also improve the distribution of income and wealth. ${ }^{24}$ The earlier discussion emphasized, too, the importance of progressive capital taxes, and how our current tax structure, which is regressive at the top, may itself be contributing to the growth of wealth inequality at the top.

Some have argued against the taxation of capital (and inheritances) on the grounds that such taxes are inefficient. The returns to capital consist of four parts: (1) the pure rate of interest - the T-bill rate; (2) the return to risk - related to the $\beta$ of the asset; (3) the excess returns from the ability of the investment manager (presumably, what he is compensated for, and typically referred to as the $\alpha$ ); and (4) rents - some of these excess returns may be related to the exercise of monopoly power or other aspects of rent seeking.

In this parsing, at most, it is the first that should not be taxed on the standard efficiency grounds that differential taxation distorts the economy, and in recent years, these returns have been very, very low. Increases in taxation of the second component (so long as there are adequate provisions for loss offsets) actually increase efficiency; well-designed higher taxation provides better risk sharing, which is especially important in the context of imperfect risk markets (Domar and Musgrave, 1944; Stiglitz, 1969a). The third component should be included in labor income, and subject to the progressive income tax. If some individuals consistently get higher risk-adjusted returns to capital, those higher returns should be ascribed to their "labor services." Indeed, those in Wall Street always claim that is why they should be well compensated. (The preferential tax treatment of carried interest is one of the ways that our tax system leads to more inequality.) The fourth component should be taxed at very high rates.

There is a practical challenge in parsing out the components, but, at the very least, this parsing of the nature of the returns to capital should make it clear that the returns to capital should be taxed, and possibly at rates even higher than those imposed on conventionally measured labor income. If one cannot parse out the different components, then the tax rate imposed should reflect the relative importance of the different components even if one were not concerned with redistribution.

Finally, I want to link this discussion with the earlier analysis of increases in wealth inequality, which showed that the increases are closely related to increases in land prices. Piketty's recent book noted the enormous increases in the wealth-output ratio in most capitalist countries in the last third of a century. But these increases have been partly,

\footnotetext{
${ }^{24}$ Even in this case, however, one has to be attentive to tax shifting, as such taxes might encourage a shift toward the transfer of human capital. But provided there is a good public education system, the effects of this shift will be limited.
} 
and in some cases largely, related to increases in the value of land. A tax on the return to land, and even more so, on the capital gains from land, would reduce inequality and, by encouraging more investment into real capital, actually enhance growth. This is, of course, an old idea, promoted most famously by Henry George (1879).

In concluding this section, let me digress briefly. The standard argument against differential taxation is based on Atkinson and Stiglitz (1976), ${ }^{25}$ in which we showed that if there is an optimal income tax, then no differential taxation on commodities is desirable. An implication is that, treating consumption at different dates as different commodities, one should not impose an interest income tax, which changes the relative price of consumption at different dates. That model entailed special technical assumptions (e.g., about the separability between consumption of all goods and leisure) that limit its applicability. Beyond that, several factors are omitted from this model.

First, there are no inheritances. If there were, and they were observable, then they would normally be taxed. How they should be taxed within the standard social welfare framework is a more complicated matter.

Second, there are no rents. As explained above, much of the seeming return to capital is actually rents, and the Henry George principle says that such rents should be taxed at 100 percent.

Third, in the Atkinson-Stiglitz framework, individuals differ in only one respect - their output per hour. But skill mixes are far more heterogeneous, and tax policy (encouraging, say, some kinds of investments and discouraging others) can affect the before-tax distribution of income just as it can affect the after-tax distribution of income.

It is, in fact, desirable for government not to just rely on ex post redistribution, but to design tax and expenditure policies, to the extent possible, that create a more equalitarian pre-tax and transfer distribution of income, reducing the burden imposed by redistributive taxation. ${ }^{26}$

\section{CONCLUDING COMMENTS}

Piketty's book provides us with a wealth of data to interpret. It had been widely recognized that inequality in most advanced countries had been increasing markedly since 1980. It had also been widely recognized that inequality was lower in the period after World War II than it had been, say, in America's Gilded Age or in the years just before the Great Depression. The juxtaposition of those two observations leads to a natural question: Was this period that I referred to earlier as the golden age of capitalism a rare exception, the result of the unusual solidarity brought about by World War II, including policies like the GI bill that provided a free college education to everyone who had fought (which was essentially every young able-bodied man)? Or did the policies that began to be instituted in the 1980s represent an aberration of the trend that Kuznets had earlier identified — of economic advances being associated with greater equality?

\footnotetext{
${ }^{25}$ The result was subsequently generalized in Kaplow (2006).

${ }^{26}$ Stiglitz $(1998,2014 b)$ provides a more extensive discussion of the issues.
} 
The general theories that I have discussed in this review, while they cannot provide a definitive answer, provide some hints. In the absence of changes in policies, such as lowering taxes on capital, standard models would not imply either the increase in the wealth-income ratio or the increase in inequality that has been observed. The standard economic model will not suffice.

One set of changes that I have not discussed are changes in technology. Technological change has made labor more productive, and at least in some areas, like computing, there have been enormous increases in the productivity of capital. Some types of labor have had their productivity increased more than others. ${ }^{27}$ Still, there should have been an increase in average wages paid (given that the rate of return to capital has remained roughly constant).$^{28}$ And these changes in technology cannot explain why there should have been such an increase in the gap between average wages (or compensation) and productivity.

This leaves two other partially related sets of explanations: (1) an increase in rents ${ }^{29}$ - an increase in land rents and land values, and an increase in exploitation rents and an associated increase in wealth that represents the capitalization of those rents; and (2) changes in public policies which are, on balance, inequality-increasing. I have shown how a variety of policies - most importantly, tax, education, antitrust, monetary, corporate governance, and regulatory policies - may have contributed to recent increases in inequality.

Americans still like to see themselves as the middle class families of the 1950s. That period, as Piketty has reminded us, was unusual, and much has happened in the last half century. The set of policy and structural changes brought on in the 1980s, here and abroad - deregulation, globalization, the lowering of marginal tax rates — did not bring about the burst of growth that had been hoped for in the United States and other advanced countries. Growth, in fact, has been markedly slower than in the decades after World War II, and the benefits of what growth there has been have gone to those at the top of the income distribution.

The title of Piketty's book and much of his analysis suggests that it is capitalism that is at fault, that this is just the way that market economies work. My analysis of market

${ }^{27}$ Although such skill-biased technological change may have played an important role in explaining wage inequalities before 2000, it is hard to see how they can account for what has happened since. It is also hard to reconcile the timing of changes in wage rates with changes either in technology or globalization. Shierholz, Mishel, and Schmitt (2013) provide a more extensive critique and review of the literature.

${ }^{28}$ This is proven in Stiglitz (forthcoming).

${ }^{29}$ There is one further category of rents that has increased - those associated with intellectual property. While important, they do not seem to be the primary drivers of the observed increases in inequality. Part of the increase in intellectual property rents is associated with the move to a knowledge economy, but part of the increase is the result of stronger intellectual property laws. While there is a debate about whether this has led to more innovation (there are reasons to believe it may have had exactly the opposite effect), it is clear that the "enclosure of the knowledge commons" (to use Boyle's term) has generated more measured wealth, appropriating benefits that would have otherwise been shared in society (Boyle, 2003; Stiglitz, 2014c). 
models suggests that there is no inherent reason that there should be the high level of inequality that is observed in the United States and many other advanced countries. It is not a necessary feature of the market economy. It is politics in the $21^{\text {st }}$ century, not capitalism, which is at fault. Market and political forces have, of course, always been interwined. Especially in America, where our politics is so money-driven, economic inequalities translate into political inequality.

There is nevertheless considerable hope. For if the growth of inequality was largely the result of inexorable economic laws, public policy could do little more than lean against the wind. But if the growth of inequality is the result of public policy, a change in those policies could lead to an economy with less inequality, and even stronger growth.

\section{DISCLOSURES}

The author has no financial arrangements that might give rise to a conflict of interest with respect to the research reported in this paper.

\section{REFERENCES}

Atkinson, Anthony B., and Joseph E. Stiglitz, 1976. "The Design of Tax Structure: Direct Versus Indirect Taxation.” Journal of Public Economics 6 (1), 55-75.

Berg, Andrew, and Jonathan Ostry, 2011. "Inequality and Unsustainable Growth: Two Sides of the Same Coin?” IMF Staff Discussion Note No. 11/08. International Monetary Fund, Washington, DC.

Bevan, David L., 1979. "Inheritance and the Distribution of Wealth." Economica 46 (184), $381-402$.

Bevan, David L. and Joseph E. Stiglitz, 1979. “Intergenerational Transfers and Inequality.” Greek Economic Review 1 (1), 8-26.

Boshara, Ray, William Emmons, and Brian Noeth, 2014. "The Great Recession Casts a Long Shadow on Family Finances." On the Economy, Federal Reserve Bank of St. Louis, St. Louis, MI, https://www.stlouisfed.org/On-The-Economy/2014/September/The-Great-Recession-Castsa-Long-Shadow-on-Family-Finances.

Bourguignon, François, 2012. La Mondialisation de L’inégalité. Editions Le Seuil, Paris, France.

Boyle, James, 2003. "The Second Enclosure Movement and the Construction of the Public Domain." Law and Contemporary Problems 66 (1), 33-74.

Bricker, Jesse, Lisa J. Dettling, Alice Henriques, Joanne W. Hsu, Kevin B. Moore, John Sabelhaus, Jeffrey Thompson, and Richard A. Windle, 2014. "Changes in U.S. Family Finances from 2010 to 2013: Evidence from the Survey of Consumer Finances." Federal Reserve Bulletin 100 (4), 1-41. Board of Governors of the Federal Reserve System, Washington, DC. 
Carroll, Christopher D., 1998. "Why Do the Rich Save So Much?” NBER Working Paper No. 6549. National Bureau of Economic Research, Cambridge, MA.

Champernowne, David G., 1953. "A Model of Income Distribution.” Economic Journal 63 (250), 318-351.

Chetty, Raj, Nathaniel Hendren, Patrick Kline, and Emmanuel Saez, forthcoming. "Where is the Land of Opportunity? The Geography of Intergenerational Mobility in the United States." Quarterly Journal of Economics.

Corak, Miles, 2013. "Income Inequality, Equality of Opportunity, and Intergenerational Mobility.” Journal of Economic Perspectives 27 (3), 79-102.

Domar, Evsey D., and Richard A. Musgrave, 1944. "Proportional Income Taxation and RiskTaking." Quarterly Journal of Economics 58 (3), 388-422.

Dynan, Karen, Jonathan Skinner, and Stephen P. Zeldes, 2004. “Do the Rich Save More?” Journal of Political Economy 112 (2), 397-444.

Galbraith, Kenneth, 2012. Inequality and Instability: A Study of the World Economy Just Before the Great Crisis. Oxford University Press, New York, NY, and Oxford, UK.

George, Henry, 1879. Progress and Poverty: An Inquiry into the Cause of Industrial Depressions and of Increase of Want with Increase of Wealth Book VI. Robert Schalkenbach Foundation, New York, NY.

Giovannoni, Olivier G., 2014. "What Do We Know about the Labor Share and the Profit Share? - Part III: Measures and Structural Factors." UTIP Working Paper No. 66. University of Texas, Austin, TX.

Giovannoni, Olivier G., 2015. "Inequality: Challenge of the Century?" Paper presented at The Preliminary Program of the Allied Social Science Association, January 3. Allied Social Science Association, Boston, MA.

Hahn, Frank, 1966. "Equilibrium Dynamics with Heterogeneous Capital Goods.” Quarterly Journal of Economics 80 (4), 633-646.

Heckman, James, 2011. "The Economics of Inequality: The Value of Early Childhood Education." American Educator 35 (1), 31-47.

Heckman, James, Rodrigo Pinto, and Peter Savelyev, 2013. "Understanding the Mechanisms through which an Influential Early Childhood Program Boosted Adult Outcomes." American Economic Review 103 (6), 2052-2086.

Hotelling, Harold, 1931. "The Economics of Exhaustible Resources." Journal of Political Economy 39 (2), 137-175.

Jäntti, Markus, Bernt Bratsberg, Knut Røed, Oddbjørn Raaum, Robin Naylor, Eva Österbacka, Anders Björklund, and Tor Eriksson, 2006. "American Exceptionalism in a New Light: A Comparison of Intergenerational Earnings Mobility in the Nordic Countries, the United Kingdom and the United States.” IZA Discussion Paper No. 1938. IZA, Bonn, Germany. 
Kaplow, Louis, 2006. "On the Undesirability of Commodity Taxation Even When Income Taxation Is Not Optimal.” Journal of Public Economics 90 (6-7), 1235-1250.

Krueger, Alan, 2012. The Rise and Consequences of Inequality. Presentation made to the Center for American Progress, Washington, DC, http://www.americanprogress.org/events/\%20/2012/ 01/12/17181/the-rise-and-consequences-of-inequality/.

Lewis, Michael, 2014. Flash Boys: A Wall Street Revolt. W.W. Norton, New York, NY.

Milanovic, Branko, 2010. The Haves and the Have-Nots: A Brief and Idiosyncratic History of Global Inequality. Basic Books, New York, NY.

Noah, Timothy, 2012. The Great Divergence: America's Growing Inequality Crisis and What We Can Do About It. Bloomsbury, New York, NY.

Organisation for Economic Co-operation and Development, 2011. Divided We Stand: Why Inequality Keeps Rising. OECD Publishing, Paris, France.

Okun, Arthur, 1975. Equality and Efficiency: The Big Trade Off. Brookings Institution Press Washington, DC.

Pasinetti, Luigi L., 1962. "The Rate of Profit and Income Distribution in Relation to the Rate of Economic Growth.” Review of Economic Studies 29 (4), 267-279.

Piketty, Thomas, 2014. Capital in the Twenty-First Century. Harvard University Press, Cambridge, MA.

Piketty, Thomas, and Emmanuel Saez, 2003. "Income Inequality in the United States, 1913-1998." Quarterly Journal of Economics 118 (1), 1-39. (Tables and figures updated to 2013, as of January 2015.)

Piketty, Thomas, Emmanuel Saez, and Stefanie Stantcheva, 2014. "Optimal Taxation of Top Labor Incomes: A Tale of Three Elasticities.” American Economic Journal: Economic Policy 6 (1), 230-271.

Piketty, Thomas and Gabriel Zucman, 2014. "Capital is Back: Wealth-Income Ratios in Rich Countries 1700-2010.” Quarterly Journal of Economics 129 (3), 1255-1310.

Roberts, Sam, 2014. "Why are Rockefellers Moving from 30 Rock? 'We Got a Great Deal."” The New York Times, November 24, http://www.nytimes.com/2014/11/24/nyregion/why-arerockefellers-moving-from-30-rock-we-got-a-deal.html?_r=0.

Saez, Emmanuel, and Gabriel Zucman, 2014. "Wealth Inequality in the United States since 1913: Evidence from Capitalized Income Tax Data." NBER Working Paper 20625. National Bureau of Economic Research, Cambridge, MA.

Shell, Karl, and Joseph E. Stiglitz, 1967. "Allocation of Investment in a Dynamic Economy." Quarterly Journal of Economics 81 (4), 592-609.

Shierholz, Heidi, and Lawrence Mishel, 2013. “A Decade of Flat Wages.” Economic Policy Institute, Washington, DC, http://www.epi.org/publication/a-decade-of-flat-wages-the-key-barrierto-shared-prosperity-and-a-rising-middle-class/. 
Shierholz, Heidi, Lawrence Mishel, and John Schmitt, 2013. "Don't Blame the Robots: Assessing the Job Polarization Explanation of Growing Wage Inequality." Economic Policy Institute, Washington, DC, http://s1.epi.org/files/2013/technology-inequality-dont-blame-the-robots.pdf.

Solow, Robert M., 1956. “A Contribution to the Theory of Economic Growth.” Quarterly Journal of Economics 70 (1), 65-94.

Stiglitz, Joseph E., 1969a. "The Effects of Income, Wealth and Capital Gains Taxation on RiskTaking." Quarterly Journal of Economics 83 (2), 263-283.

Stiglitz, Joseph E., 1969b. "Distribution of Income and Wealth Among Individuals." Econometrica 37 (3), 382-397.

Stiglitz, Joseph E., 1998. "Pareto Efficient Taxation and Expenditure Policies, With Applications to the Taxation of Capital, Public Investment, and Externalities." NBER Working Paper No. 6610. National Bureau of Economic Research, Cambridge, MA.

Stiglitz, Joseph E., 2012. The Price of Inequality: How Today's Divided Society Endangers Our Future. W.W. Norton, New York, NY.

Stiglitz, Joseph E., 2014a. “Tapping the Brakes: Are Less Active Markets Safer and Better for the Economy?" Paper presented at the Federal Reserve Bank of Atlanta 2014 Financial Markets Conference Tuning Financial Regulation for Stability and Efficiency, April 15. Atlanta, GA, http://www.frbatlanta.org/documents/news/conferences/14fmc/Stiglitz.pdf.

Stiglitz, Joseph E., 2014b. "In Praise of Frank Ramsey's Contribution to the Theory of Taxation." NBER Working Paper No. 20530. National Bureau of Economic Research, Cambridge, MA.

Stiglitz, Joseph E., 2014c. "Intellectual Property Rights, the Pool of Knowledge, and Innovation." NBER Working Paper No. 20014. National Bureau of Economic Research, Cambridge, MA.

Stiglitz, Joseph E., forthcoming. "New Theoretical Perspectives on the Distribution of Income and Wealth Among Individuals." Forthcoming in the proceedings of the $17^{\text {th }}$ World Congress of the International Economics Association, Dead Sea, Jordan.

Stiglitz, Joseph E., Amartya Sen, and Jean-Paul Fitoussi, 2010. Mismeasuring Our Lives: Why GDP Doesn't Add Up. Report of the International Commission on the Measurement of Economic Performance and Social Progress. The New Press, New York, NY.

Wilkinson, Richard, and Kate Pickett, 2010. The Spirit Level: Why More Equal Societies Almost Always Do Better. Bloomsbury Press, New York, NY. 